\title{
Implementation of State Obligations and Responsibility Ensuring the Availability of Clean Water in Karimunjawa Islands
}

\author{
Rahayu ${ }^{1,2, *}$, Tri Retnaningsih Soeprobowati ${ }^{2,3}$ \\ ${ }^{1}$ Faculty of Law, Diponegoro University \\ ${ }^{2}$ School of Postgraduate Studies, Diponegoro University \\ ${ }^{3}$ Faculty of Science and Mathematics, Diponegoro University
}

\begin{abstract}
This article aims to analyze the implementation of state obligations and responsibility ensuring the availability of clean water as part of human rights in Karimunjawa islands. The analys is based on principle of the State obligations and responsibility to fulfill their citizen right. Water sources in Karimunjawa Islands is very limited. It depend on forest conservation. Around 9.600 peoples live in Karimunjawa Islands, but Karimunjawa is non groundwater basin region. It means, Karimunjawa doesn't have groundwater potential. The quantity of water depends on the season. The solution to maintain the sustainability of clean water is piping from water reservo ir to residential areas. The problem is there are so many hotels in Karimunjawa is lands, it disrupted the fulfillment of clean water. Besides utilizing water from reservoir, many hotels drilled the ground to get water. It had impact to the availibity of water in dry season and affected to fulfillment of water supply for Karimunjawa people. There is no specific regulation and policy to solve this problem. Clean water management is doing by Karimunjawa's people. Meanwhile, based on Mahkamah Konstitusi Decree number 85/PUU-XI/2013, state is a rights holder to dominate the water in accordance with the Articles 33 paragraph (2) and (3) UUD NRI 1945, so the government has an obligation to make a policy, regulations, management, and supervision.
\end{abstract}

\section{Introduction}

\subsection{Background}

Water is the source of life. For human, water possesses social, economic, and religious values and functions. Water resources have always become actual issues because the right of water is fundamental for human life. In practice, however, the need for clean water for most people in the world, including in Indonesia, has never been fulfilled.

Global water problems also indicate the similar problems with that of Indonesia. Naturally, Indonesia is the fifth richest country in the world, having an annual rainfall rate of $2,799 \mathrm{~mm}$, with a great deal of water resource potential. However, such abundance raises some problems because of inequal distribution through the year. Due to global climate change, the climate pattern continues to change significantly. Rainy season in particular country will affect the climate of the other country. Therefore, water climate-related water problems are considered global issues, no longer local or national ones [1].

International community concern of the waterrelated problems has been indicated by an agreement of global development by the issuance of a document namely 'Sustainable Development Goals' (SDGs). This document is signed by 193 country members of the United Nations at the General Assembly on September 25, 2015 in New York. The SDGs document promotes 17 goals and 169 development objectives and its sixth goal, 'clean water and sanitation', requires the sustainable clean water and sanitation for everyone.

Karimunjawa Islands, one of districts in Jepara Regency, are regions with limited clean water, in particular when it comes a dry season. In the dry season, many local people use brackish water to fulfill their daily necessities. The islands lack water supply and have a forest zone conservation area. A policy is necessary to regulate the water supply and use to ensure the sustainable right of water for the local people of the Karimunjawa Islands. The obligation to fulfill the need for clean water is among the primary responsibilities of the government.

Indonesia is a country where mutual welfare has become the ultimate objective. This concept is not only becoming a legal image (rechtsidee), but also a state image (staatsidee). From the concept of welfare state, the state does not only act as security and tranquility watch for its people, but also has a responsibility for putting in practice social justice, mutual welfare and people prosperity [2-3] 


\subsection{Theory}

\subsubsection{Policy on Water Resource Management}

Water resource is understood as a capacity and potential of water to be exploited by human for social-economic activities. There are different water resources that can be used by the community, such as marine/sea water, surface water, rain water, and ground water. The use and control of water resources deal with water quality and quantity. Water quality is an important point in the water exploitation because it does not only depend on how much water that can be obtained to fulfill the needs, but also how much the quality of the water in line with the human needs [4].

In terms of water resource management as part of the natural resources, the government has an authority to issue related policies, laws and licenses. Since the Decree of Constitution Court 85/PUU-XI/2013, which negated Law 7/2004 on Water Resources, has been taken in effect, the water management has once again referred to the Law 11/1974 on Water Management [5]. According to the Law 11/1974 water resources are water places and media, either over or under the land surface (Article 1, point 4). Water and the water sources, including their natural richness, have social functions by which the people can exploit and use for their prosperity. The Law also requires that the water and the water resources are possessed by the state, pursuant to the Constitution of the Republic of Indonesia 1945, Article 33(3).

According to the Decree of the Constitution Supreme Court, the state expands its authority as it has responsibility to make policy (beleid), regulation (regelandaad), provision (bestuursdaad), management (beheersdaad), and monitoring (toezicthoudensdaad) [5]. These five authorizing functions become integrated instruments for the state towards the ultimate goal, i.e. prosperity for the all citizens. Therefore, the phrase 'to be possessed by the State' in the Article 33(3) of the 1945 Constitution must be understood within the concept of public law related to the principles of people sovereignty within the 1945 Constitution, either those concerning political democracy or economic democracy. It does necessarily mean that 'to be possessed' is 'to be owned' [6].

\subsubsection{Citizen's right on water under legal standard and norm and State's obligations to fulfill}

In principle, water is the essence of life because its existence is indispensable. Like oxygen, human cannot live without water. Even, every living creature on this planet will not survive without water. Therefore, water is the most fundamental right for mankind.

In addition to object, right is the object of law that can be controlled or owned by legal subjects. In general, rights can be distinguished into absolute rights and relative rights. Human rights are included in absolute rights.

Vary legal instruments promoted at international level indicate that water is not only the right, but also an aspect in which the access must be enabled for everyone. In other words, water has also become the part of human rights. Such defense has been promoted by the UDHR (Preambule and Article 3); Decision 1999/108 the
United Nations on Human Rights; Resolution of Sub Commission on Prevention of Discrimination and Protection of Minorities 1998/7; Resolution Number 2000/8 Sub-Commission on Human Rights; "Promotion of the Realization of the Rights of Drinking and Sanitation"; Resolution of Commission on Human Rights 2003/71; "Human Rights and the Environment as part of Sustainable Development"; Article 11 and 12 International Covenant on Economic, Social and Cultural Right (ICESCR); etc. In the General Comment No. 14/2008 CSECR, in particular in the paragraph 12, the right of access to water comprises four elements, i.e. availability, accessibility, acceptability, and quality. Accessibility relates to respect for non-discriminatory principle, physical and economic access, and information.

In the context of the national law of Indonesia, the right of water has been constitutionally given under the 1945 Constitution, Articles 28A and 28B, 33(2) and 33(3). Furthermore, its implementation also has already been regulated, such as by Law 39/1999, in which Article 77 requires that "the government has an obligation to and responsibility for the respect, protection, enforcement, and honor the human rights under this Law, other regulations, and any international law concerning the human rights...". It means that the state has the obligation in three different matters, i.e. (1) to respect by self-control of any possible human rights violation, such as polluting rivers by which the people use for daily activities; (2) to protect by taking measures to prevent third parties' vilation of the important elements of the right of water; and (3) to fulfill by taking legislative, administrative, budgetary, and judiciary measures to fulfill the need for and the right of water. These obligations point at the involvement level of the state and government [7].

\subsection{Research Method}

In this research social reality is defined as a reality that becomes part of the awareness, knowledge of society within a State. The social reality that underlines this research is the empirical reality, the reality that seems visible and is believed to be the real reality [8].

\subsubsection{Research approach}

This research applied a socio legal study approach. Such approach requires that legal aspect cannot only be conceptualized as a norm, but also a means of behavior. Therefore, the investigation of realties is expected to give the light whether the positive law or normative law within the patterns between subjects in the community have been fairly applied.

The use of socio legal study approach is necessary because a phenomenon cannot be solved only by providing information about the legal regulations. Instead, it also has to integrate approaches from other perspectives based on reality towards the ultimate goal of the law, i.e. creating regularity, justice, and prosperity. 


\subsubsection{Research type and materials}

This research applied a qualitative-descriptive method with the aim at providing description of the right of water fulfillment for the local people of Karimunjawa Islands amidst the lacking clean water supply by exploration and clarification of the object under observation.

Data used for the research were both primary and secondary. The primary data were obtained by indepth interview and focus group discussion with key informants. These data implied legal attitudes and behaviors of the local people of Karimunjawa Islands to fulfill their right of the clean water. Whereas, the secondary data were collected from literature study and documentary study, in the forms of primary, secondary, and tertiary legal materials.

\subsubsection{Research Output Analysis}

The data obtained were subject to qualitative analysis, which went on the following steps:

1.3.3.1 Data reduction, irrelevant data elimination, data unit abstraction;

1.3.3.2 Categorization, data were categorized;

1.3.3.3 Category correlation and correlated interperpretation;

1.3.3.4 Interpretation and conclusion.

\section{Results and Discussion}

\subsection{Access to clean water for local people of Karimunjawa Islands}

The Karimunjawa Islands are under the administrative area of Jepara Regency, Central Java Province. This area becomes one of districts, which consists of four villages and 12 neighborhood area $(d u k u h)$. The islands spread 125 kilometer square on the geographical coordinate of $110^{\circ} 05^{\prime} 57-110^{\circ} 31^{\prime} 15$ East and $5^{\circ} 40^{\prime} 39-5^{\circ} 55^{\prime} 00$ South and are parts of the Java Sea group of islands. They are situated Northwest of the capital city of Jepara surrounded by the Java Sea. Karimunjawa Islands are composed of 27 islets and atolls, only four of them are inhabited with the total population of 9,802 [9].

Karimunjawa Islands do not have big rivers, but they possess five water springs, i.e. Kapuran (Pancuran Belakang), Legon Goprak, Legon Lele, Cikmas and Nyamplungan. These water springs are used by the locals for daily needs. According to Peta Cekungan Air Tanah established during RAKEPRES Tentang Cekungan Air Tanah dated September 17, 2007, the Karimunjawa Islands do not have ground water potenial and are included in the Non-CAT category. Water resources in the islands are merely dependent on surface water and season [10-11].

Water quantity in the islands fluctuated seasonally so that it was unpredictable. Effort had to be made towards sustainable supply for the local people. The government had provided pipelines by connecting points of water springs to settlements. Such effort was coordinated by a community union for clean water work unit namely "TIRTA KENCANA KARIMUNJAWA" [9]. The unit was established under the Letter of Decree of Karimunjawa District Head and was composed of local people to organize and to manage water distribution for mutual needs, in particular households in the islands. In addition, in some islets, such as Kemujan, Parang, and Nyamuk, where the water springs was not found, the people digged 8-20 meter deep wells to get the ground water for their daily needs [9].

Karimunjawa Islands were the home for 9,802 population with the domestic water need of $60-100$ litres/individual/day. Whereas, non-domestic water needs consisted of commercial use, institutional need, and industrial needs, which could only apply to an area with less than 100,000 population. There was ony $25 \%$ of the total water needs for households and domestic needs. According to water availability compared to the population size, the water need in Karimunjawa Islands had been fulfilled, although the population kept growing annually and the water supply was constant. Problems arose when Karimunjawa Islands began to develop resort nd hotels for tourism activities.

Of five hotels and two resorts available in the Karimunjawa Islands, one needed to drill the ground water and the rests still depended on pipeline systems from the Karimunjawa National Park. The drilling activity affected the clean water supply in the dry season, in which water springs began to dry. It was predicted that the local people will no longer have access to the water if the drilling continues and the resorts and hotels grow in numbers.

\subsection{State obligation and responsibility for clean water availability in Karimunjawa Is lands}

Dynamic development of and change in aspects of life, nationwide or worldwide, have contributed to the shortage of water resources due to severe crises. The change in land function and environmental destruction have worsened the situation and damaged the water quantity and quality. The population boom and economic growth need more supplies of water than ever before.

In terms of Indonesia, the use of water must be monitored and supervised by the government because water is a res commune. It is what the 1994 Constitution requires in Article 33(2) and 33(3), along with Article $28 \mathrm{H}$, in which water is part of human rights with nonderogable nature. Furthermore, Indonesia has also ratified ICESCR in the Law 11/2005. At international level, in addition to the ICESCR, the right of water has been also pointed by the General Comment No. 15 (2002) adopted by the UN Committee on ECSCR entitled 'the right to water'. Some of these legal norms, either at national or international scales, have exemplied the legal stance of the right to water as part of the human rights. In consequence, the state has obligation to 
respect, to fulfill, and to protect the right to water of everyone indiscriminately [7].

Concerning the water management in the Karimunjawa Islands to fulfill the needs for water, it is important to notice that the islands have difficulties to find the water sources. The limited supply of water at the conservation area must be taken account seriously and wisely. The government has a responsibility for performing five duties as follows:

Firstly, the government, i.e. Local Government of Central Java and Local Government of Jepara Regency, have responsibilities for determining a policy line (beleid) on the waer use in the Karimunjawa Islands. The policy made by the Local Governments should not be apart from legal politics already required by the 1945 Constitution, in particular Article 33(2) and 33(3). It means that the policy on the water use in Karimunjawa Islands must consider the aspect of right fulfillment while consistently protecting the forest sustainability as the main sources of the water. The local governments must firmly decide what can be done or want cannot be done by the local people towards the access to water. The geographical condition where the water supply in the Karimunjawa Islands is situated makes the islands depend on the forest as the major water supplier. A clear and rigid regulation is necessary to fill technological gaps applied by the local people to access the water.

Secondly, the state as the possessing party must establish and decide regulation (regelandaad). In case of the water use in Karimunjawa, no regulation has been made by ether provincial or regency governments. Therefore, daily and business activities related to the water use in the islands have not been under control. The regulation is greatly needed to manage the access to the water towards it sustainability.

Thirdly, the state has a mandatory to take a provision (bestuursdaad), which means that it must fulfill the water need in Karimunjawa Islands, in partiular the local governments. Even though in the context of the water management the responsibility is within the hand of the government, but the Leter of Decree on Karimunjawa Islands also requires a concerted work between the local government and the local communities at the district level by establishing a work unit an license from the Karimunjawa National Park Office. They represent the government at the local level and facilitate the need for water. However, the differentiation between the household need and business need (for resort and hotel) has not been explained and regulated.

Fourthly, the state has a responsibility for management (beheersdaad) as required by the previous paragraphs that the water management in Karimunjawa Islands have not been directly performed by the government. Instead, it is managed by a self-sufficient local dwellers.

Fifthly, the state, in performing the rights of water possession, is responsible for monitoring (toezichtthoudensdaad). Hence, because the water sources are situated in the Karimunjwa National Park, the monitoring is performed by District Government and the Karimunjawa National Park Office, in particular those concerning license prolongation.

\section{Conclusion}

Karimunjawa Islands do not have plenty of water sources. The limited supply requires a wise management by considering fair distribution while paying attention to environmental sustainability. No policy has been made on the water resources and its sustainable use in the Karimunjawa Islands.

Water management in the Karimunjawa Islands, in particular those related to distribution for the local people need, was still managed locally by the local people under the permission of the District Government and the Karimunjawa National Park Office. No regulation has been established for water use and water access. The differentiation between the household need and business need (for resort and hotel) has not been explained and regulated.

\section{References}

1. Irianto, Air dan Perubahan Iklim Global, Kompas, 10 Juni 2003.

2. Bagir Manan, Politik Perundang-undangan Dalam Rangka Mengantisipasi Liberalisasi Perekonomian, Makalah FH UNILA, Lampung, 1996.

3. Nanik Tri Hastuti, Community Development di Sektor Pertambangan Ditinjau dari Kosep Negara Kesejahteraan, Masalah-Masalah Hukum FH UNDIP, Vol. XXXIII No. 1 Januari-Maret 2004.

4. Raja Siregar, Privatisasi Air, dalam WWW.Wahli.or.id.

5. Decree of Constitution Court Number : 85/PUU$\mathrm{XI} / 2013$.

6. Yance Arizona, Konstitusionalisme Agraria, (Yogyakarta : STPN Press, 2014).

7. Rahayu, Hukum Hak Asasi Manusia, (Semarang : Badan Penerbit Universitas Diponegoro, Edisi Revisi 2015).

8. Adji Samekto, "Perkembangan Ranah Kajian Hukum”, Orasi Ilmiah yangDisampaikan pada Dies Natalis Ke-48 Fakultas Hukum UNDIP di Semarang pada 9 Januari 2005.

9. Laporan Akhir "Kajian Nilai Ekonomi Pemanfaatan Sumber Daya Air Taman Nasional Karimunjawa" tahun 2010.

10. Robert J. Kodoatie and Roestam Sjarief, Tata Ruang Air, (Yogyakarta : Penerbit Andi, 2010).

11. Kodoatie, Robert dan M. Basoeki, Kajian Undang Undang Sumber Daya Air, (Yogyakarta : Andi Offset, 2005). 